\title{
PROFIL KULI PANGGUL PEREMPUAN DESA SELOTINATAH KECAMATAN NGARIBOYO KABUPATEN MAGETAN
}

\author{
Farah Wahyuni Idha Salasin \& Yudi Hartono*
}

\begin{abstract}
Abstrak
Penelitian ini bertujuan untuk mengetahui profil akan kuli panggul perempuan, terkait dengan kesejarahan kuli panggul, faktor-faktor yang mendasari bekerja sebagai kuli panggul serta interaksi kuli panggul baik dengan keluaraga, masyarakat serta antar kelompok kuli panggul di pasar sayur kota Magetan. Lokasi penelitian di Desa Selotinatah Kecamatan Ngariboyo, Kabupaten Magetan. Sumber data berupa Informan, Arsip dan Dokumen. Informan dalam penelitian ini adalah perangkat desa Selotinatah, Ketua SPSI Cabang pasar sayur magetan dan Kuli panggul perempuan dari Desa Selotinatah. Sedangkan Arsip maupun dokumen yang digunakan meliputi bahan pustaka, data dari SPSI Cabang Pasar Sayur Magetan, profil desa Selotinatah serta Data dari BPS. Dalam pengumpulan data peneliti menggunakan wawancara (Interview), Observasi dan dokumentasi. Validasi yang digunakan untuk menguji kebenaran data dengan menggunakan triangulasi sumber penelitian. Sedangkan analisis data menggunakan tiga teknik yakni reduksi data, penyajian data dan penarikan kesimpulan atau verifikasi.

Hasil penelitian menunjukkan bahwa kuli panggul perempuan di Desa Selotinatah bisa dikatakan telah membudaya, padahal untuk sekarang bagi perempuan menjadi TKW menjadi primadona dalam bekerja. Meskipun begitu, pemilihan pekerjaan ini tidak lain bagi perempuan, tetap ingin menjalankan perannya sebagi ibu rumah tangga. Pekerjaan sebagai kuli dijalani oleh perempuan desa Selotinatah sejak tahun 1970-an. Faktor yang mendasari mereka memilih bekerja sebagai kuli selain ketersediaan pekerjaan di desa juga dipengaruhi oleh faktor pendidikan serta topografi desa Selotinatah. Terkait dengan interaksi baik dengan keluarga, masyarakat dan antar sesama kuli panggul tetap dapat terjalin dengan berbagai kegiatan khusus perempuan "ibu-ibu" baik di desa maupun di pasar sendiri.
\end{abstract}

\section{Kata Kunci: Kuli, Perempuan}

\section{Pendahuluan}

Masyarakat Indonesia sebagian besar bercirikan agraris. Basis kehidupan masyarakat agraris adalah desa. Keberadaan desa sangat penting, karena desa merupakan tempat penyedia bahan baku pangan, produksi dan tenaga kerja. Adanya fungsi tersebut, maka pantas jika dikatakan desa merupakan jantung kehidupan masyarakat kota dalam menstabilkan gerak sosial ekonomi. Pembahasan tentang desa akan terkait dengan masyarakat serta segala aspek kehidupannya.

Menurut Sutardjo Kartodikusumo (dalam R. Bintarto, 1984:13) "Desa ialah suatu kesatuan hukum di mana bertempat tinggal suatu masyarakat yang berkuasa mengadakan pemerintahan sendiri”. C.S.T Kansil, dkk (2004:56) mengemukakan pengertian desa “.... dalam perkembangan sejarah ketatanegaraan dan tata pemerintahan sampai sekarang merupakan suatu wilayah yang ditempati sejumlah

* Farah Wahyuni Idha Salasin adalah Alumni Pendidikan Sejarah IKIP PGRI MADIUN

* Yudi Hartono adalah Dosen Pendidikan Sejarah IKIP PGRI MADIUN 
penduduk yang mempunyai organisasi pemerintahan terendah langsung di bawah camat, telah memiliki hak menyelenggarakan rumah tangganya".

Menurut Peraturan Pelaksanaan Pemerintahan Republik Indonesia Nomor 72 Tahun 2005 Tentang Desa Bab IV Daerah Peraturan Pemerintahan Tentang Desa pasal 1 (2006:23), pengertian desa sebagai berikut.

"Desa atau yang disebut nama lain, selanjutnya di sebut desa, adalah kesatuan masyarakat hukum yang memiliki batas-batas wilayah yang berwenang untuk mengatur dan mengurus kepentingan masyarakat setempat, berdasarkan asal-usul dan adat istiadat setempat yang diakui dan dihormati dalam sistem Pemerintahan Negara Kesatuan Republik Indonesia."

Berdasarkan pengertian-pengertian di atas, dapat disimpulkan bahwa desa merupakan kawasan tempat tinggal sekelompok manusia yang memiliki batasan wilayah dan peraturan yang sesuai dengan karakter setiap wilayah, serta berhak mengatur pemerintahan desa yang mempunyai status hukum yang diakui Negara.

Ada beberapa unsur desa. Menurut R. Bintarto (1984:14), unsur-unsur desa yaitu:1) Daerah, 2) Penduduk dan 3) Tata Kehidupan. Daerah pedesaan tidak terlepas dari pertanian. Hal ini akan terkait bahwa desa merupakan jantung kehidupan kota, meski keadaan kemakmuran dan kemajuan suatu desa akan berbeda. Perbedaan itu dipengaruhi oleh faktor tata geografi (geografi setting) dan usaha manusia (human efforts) dalam memanfaatkan desanya. Ketersedian lahan di desa mendorong masyarakat memanfaatkannya sebagai lahan tanaman pokok, yang disesuaikan dengan keadaan alam terkait dengan tanaman komoditus yang dapat di tanam serta dapat meningkatkan perekonomian masyarakat pedesaan.

Unsur desa yang kedua adalah penduduk atau masyarakat. Pengertian masyarakat menurut Koentjaraningrat (dalam Abraham Nurcahyo dkk, 2009:48) masyarakat sebagai kesatuan hidup manusia yang berinteraksi menurut suatu sistem adat istiadat tertentu yang bersifat kontinu dan yang terikat oleh suatu rasa identitas bersama. Sedangkan, Unsur yang ketiga adalah tata kehidupan. Menurut R. Bintarto (1984:14) tata kehidupan dalam hal ini adalah pola tata pergaulan dan ikatan-ikatan pergaulan warga desa. Jadi, menyangkut seluk-beluk kehidupan masyarakat desa.

Besarnya jumlah penduduk desa menjadikan surplus tenaga di sektor pertanian. Hal ini menjadikan masyarakat menyalurkan tenaga di sektor ekonomi yang lain. Selain itu, sektor pertanian bagi masyarakat desa hanya bersifat musiman saja, sehingga tidak mampu menghasilkan 
pendapatan setiap harinya baik bagi pemilik tanah maupun buruh tani.

Sektor nonpertanian yang berperan dalam pengalokasian tenaga kerja masyarakat pedesaan, selain mencari pekerjaan ke kota, bisa dengan kegiatan industri rumah-tangga/kerajinan rakyat yang berskala rumahan. Industri kerajinan rumah tangga bisa menjadi pilihan bagi masyarakat, biasanya hal ini disesuaikan dengan komuditi kerajinan yang ada di suatu desa. Kondisi kerajinan ini biasanya terkait dengan icon suatu desa maupun daerah, yang dapat menarik wisatawan. Namun, ada pula yang menjalankan usaha kerajinan karena kreatifitas, dengan begitu usaha kerajinan tetap ada dan tentunya membuka lahan pekarjaan baru. Selain industri kerajinan ada pula usaha/buruh non pertanian seperti pekerja bangunan, galian dan angkutan.

Usaha kerajinan dalam Ravik Karsidi (2003: 142) merupakan pekerjaan yang lebih "halus" dari pada bertani, ini dikarenakan anggapan masyarakat jika seorang pengrajin lebih tinggi strata sosialnya dari pada petani. Kegiatan mengrajin ini kebanyakan dilakukan oleh kaum perempuan. Pekerjaan ini dilakukan juga sebagai pengalihan tenaga kerja selama menunggu masa tanam maupun masa panen tiba. Walaupun begitu, tidak dipungkiri jika usaha kerajinan menjadi pekerjaaan yang utama bagi sebagian masyarakat. Meskipun ada sebagian masyarakat yang menggunakan sektor kerajinan dijadikan pekerjaan yang utama. Walaupun mengrajin sebenarnya masyarakat masih mempunyai keterkaitan dengan sektor pertanian, seperti ungkapan masyarakat dalam Ravik Karsidi (2003: 146) "nasinya dari sawah lauknya dari industri". Namun, jika dalam sektor kerajinan ini tidak tersedia atau tidak mampu menyerap tenaga kerja di desa, maka urbanisasi menjadi pilihan untuk mencari penghidupan/kerja selanjutnya.

Urbanisasi menjadi daya tarik, disebabkan oleh beberapa faktor. Menurut Soerjono Soekanto (2001:173-174) sebab urbanisasi yaitu faktor pendorong dari desa ke kota dan faktor daya tarik kota. Faktor yang mendorong penduduk desa untuk meninggalkan daerah kediamannya (Push Factors) diantaranya: kurangnya lapangan kerja di desa. penduduk muda merasa tertekan dengan adat istiadat di desa, di desa tidak banyak kesempatan untuk menambah pengetahuan, rekreasi yang merupakan faktor penting dalam spiritual dan bagi masyarakat yang mempunyai keahlian selain bertani, menginginkan pasaran yang lebih luas, yang tidak di dapatkan di desa.

Faktor kota yang menarik penduduk desa untuk pindah dan menetap di kotakota (Pull Factors) diantaranya: anggapan penduduk desa jika di kota banyak lapangan kerja dan penghasilan, di kota lebih banyak kesempatan mendirikan perusahaan industri dan lain-lain, kelebihan modal di 
kota lebih banyak daripada di desa, pendidikan di kota terutama lanjutan lebih banyak, kota merupakan tempat yang menguntungkan untuk mengembangkan jiwa dan kota memiliki tingkat budaya yang tinggi. Kondisi tersebut yang mendorong perempuan maupun laki-laki untuk berurban ke kota. Kerasnya persaingan kerja di kota, tanpa adanya ketrampilan yang mereka miliki memaksa untuk bekerja apa saja, yang terpenting bagi mereka bukan pekerjaannya di kota melainkan hasilnya yang ingin dicapai yaitu uang.

Dengan pilihan pekerjaan yang ada, para perempuan memilih menjalani pekerjaan sebagai kuli/tenaga jasa. Selain, karena tuntutan kebutuhan rumah tangga juga disebabkan karena sektor pertanian hanya bersifat musiman. Namun tidak dipungkiri, bagi kaum perempuan yang awalnya bekerja menjadi kuli panggul beralih menjadi pedagang didesanya. Lain dari pada itu, bagi perempuan selain bekerja menjadi kuli panggul, apabila memiliki kualifikasi pendidikan yang memadai, memiliki modal serta kecakapan berdagang perempuan tersebut memilih menjadi pedagang. Sektor perdagangan ini mempunyai peranan dalam menciptakan kesempatan kerja secara mandiri. Meski, usaha perdagangan yang mereka lakukan bukan yang berskala besar.

Mubyarto (1985: 191) membagi jenis perdagangan yang berkembang dipedesaan, yaitu : pedagang warung, pedagang keliling hasil pertanian, pedagang Es/Bakso dan perdagang keliling dalam desa/luar desa. Namun bagi mereka yang tidak memiliki kualifikasi pendidikan dan tidak memiliki modal yang memadai untuk melakukan kegiatan berdagang, maka memilih pekerjaan yang mengandalkan kekuatan fisik. Keadaan seperti itulah yang menjadi gambaran latar belakang kaum perempuan Desa Selotinatah menjadi kuli panggul di pasar. Menjadi kuli panggul di pasar sayur karena psar ini secara umum menjadi tempat translit pertama sayuran dari pengepul suatu desa yang menjadi sentral penghasil sayuran, kemudian berlajut ke pedagang eceran.

Pekerjaan kuli panggul merupakan pekerjaan dalam bidang informal, sehingga tidak memerlukan adanya standart pendidikan maupun seleksi yang rumit bagi yang ingin bekerja. Selain itu, dalam memulai pekerjaan tidak diperlukannya modal serta ketrampilan atau kecakapan tertentu. Kuli panggul di pasar sayur Magetan memiliki kelompok-kelompok, dimana kelompok ini bertujuan sebagai pengorganisir dalam penyampain informasi dari ketua SPSI (Serikat pekerja seluruh Indonesia) cabang pasar sayur magetan terkait acara rutin dalam kelompokkelompok besar kuli panggul seperti arisan.

Kerja sebagai kuli panggul dijalani kaum perempuan masyarakat Desa Selotinatah sejak lama atau bisa dikatakan telah membudaya. Melihat kondisi zaman 
saat ini, masih saja warga desa Selotinatah tetap menjalani pekerjaan tersebut, sementara banyak di desa yang lain kaum perempuan lebih memilih untuk mengadu nasib/bekerja di negeri orang dengan pertimbangan hasil yang didapatkan lebih berarti. Dalam eksistensi menjamurnya pengiriman TKI (Tenaga Kerja Indonesia) khususnya TKW (Tenaga Kerja Wanita) ke luar negeri, ternyata masih ada kaum perempuan Desa Silotinatah yang menjalani pekerjaan kasar sebagai kuli panggul. Kenyataan ini menarik bagi penulis untuk menelaah mengenai sejarah, faktor - faktor yang mem-pengaruhi menjadi kuli panggul dan kehidupan sehari-hari kuli panggul perempuan di Desa Selotinatah Kecamatan Ngariboyo Kabupaten Magetan.

\section{Tujuan dan Manfaat Penelitian}

Tujuan yang hendak dicapai dari penelitian adalah mengenai sejarah, faktor faktor yang mem-pengaruhi menjadi kuli panggul dan kehidupan sehari-hari kuli panggul perempuan di Desa Selotinatah Kecamatan Ngariboyo Kabupaten Magetan. Penelitian ini diharapkan dapat bermanfaat sebagai berikut.

1. Sebagai kajian bahwa perempuan sekarang juga telah berperan dalam peningkatan ekonomi keluarga. Pemahaman dalam bentuk emansipasi perempuan yang sederhana.

2. Diharapkan hasil penelitian ini dapat digunakan sebagai masukan untuk penelitian sejarah sosial lebih lanjut dan dapat dipergunakan untuk pembedaharaan perpustakaan.

3. Untuk mengkaji kehidupan masyarakat desa Selotinatah terkait dengan SDM (Sumber Daya Manusia) dan SDA (Sumber Daya Alam) sehubungan dengan potensi alam dan kemampuan masyarakat dalam mengembangkan potensi yang ada.

\section{Kajian Teori}

A. Kuli

Kuli sebagai salah satu jenis pekerjaan dapat di bagi menjadi kuli profesional dan kuli kasar. Kata kuli sendiri tersinonim dengan kata buruh, hal ini yang membedakan dalam perkembangan penggunaan istilah.

\footnotetext{
"Kata buruh dalam hukum positif Indonesia mendefinisikan buruh sebagai orang yang bekerja untuk orang lain dengan mendapatkan upah, sebagaimana termuat dalam UU No. 21/2001 tentang Serikat Buruh. Secara sosiolagis buruh terdefinisi sebagai kelompok masyarakat yang berpenghasilan sangat rendah, sehingga digolongkan ke dalam kelompok masyarakat pinggiran (marginal)". (Dalam Umnia Labibah, 2004:27-28)
} 
Menurut Basir Barthos (2001:19) buruh atau karyawan adalah mereka yang bekerja pada orang lain atau instansi/kantor perusahaan dengan menerima upah/gaji baik berupa uang maupun barang, seperti: pegawai negeri/swasta, buruh tani, dan sebagainya. UU Ketenagakerjaan No 13 Tahun 2003 Pasal 1 pekerja atau buruh adalah setiap orang yang bekerja dengan menerima upahan atau imbalan dalam bentuk lain. Pengertian tersebut hanya sebagai penggambaran buruh yang secara umum sama denga kuli, meski secara inti juga berhak mendapatkan upah dari penggunanya.

Awal keberadaan kuli berhubungan dengan sejarah munculnya perkebunan di Indonesia pada masa penjajahan. Upaya yang dilakukan penjajah dalam mengeksploitasi hasil bumi, dalam pemanfaatan kesuburan tanah di Indonesia. Kemunculan kuli pada masa perkebunan (onderneming) yang berada di luar Jawa seperti Sumatera, sehingga perlu mendatangkan pekerja dari Jawa. Tawaran bekerja ini di terima oleh masyarakat Jawa dengan antusias, karena masalah kemiskinan yang melanda. Namun, mereka tidak tahu jika bekerja disana mereka menjadi kuli. Hal ini perlu dimaklumi, karena mereka petani yang buta huruf dan minim pengetahuan. Proses bekerja juga dimulai dengan pendatanganan ikatan kerja (perjanjian kerja) yang salah satu isinya mereka bekerja selama 10 jam perhari. Kuli dalam bahasa belanda adalah Koelie (dalam R.P. Suyono, 2005: 101-105)

Perkembangan akan kuli di Indonesia ada tiga jenis, yaitu kuli kenceng, kuli setengah kenceng dan kuli kendho. Kuli Kenceng merupakan pekerja yang memiliki kewajiban penuh melaksanakan pekerjaannya atau tanggung-jawabnya/pekerja tetap. Menurut Jan Breman (1986:12,14) setiap penggarap menjadi sikep (peserta pemilik tanah persawahan), yang harus menyediakan jasa tenaga. Orang sikep biasa dikenal juga wong kenceng yang ditempat lain disebut juga Kuli kenceng. Dalam Suhartono (1991: 34) Kuli Kenceng adalah lapisan masyarakat paling atas, yakni lapisan yang menguasai tanah, pembayaran pajak tanah dan wajib kerja serta patuh kepada raja, terkait dengan kuli setengah kenceng dan kuli kendho merupakan kuli/pekerja yang sedang menunggu giliran tanah garapan.

Penggolongan di atas didasarkan pada tanggung jawab seseorang dalam melaksanakan pekerjaan tersebut atau keterikatan pekerja dengan pekerjaan yang dilakukan. Menurut Umnia Labibah (2004:58) industri yang dikembangkan 
pemerintahan Belanda adalah perkebunan dan sedikit industri manufaktur. Kebijakan yang dilakukan oleh belanda ini bertujuan untuk mengeruk sumber daya Indonesia dan mengusai pekerja dengan biaya murah. Masa ini bercirikan eksploitasi buruh dipedesaan.

\section{Perkembangan sistem} perkebunan awalnya dari adanya penerapan sistem sewa tanah oleh Belanda, masyarakat menyewakan tanah dengan berbagai aturan yang diterapkan oleh Belanda. Setelah dirasa oleh Belanda berhasil, maka pemerintah Belanda melancarkan sistem terbaru yakni tanam paksa. Penguasaan tanah yang dilakukan Belanda tersebut menjadikan tanah sewa dari warga dijadikan perkebunan. Menurut Warwati Djoened dan Nugroho $\mathrm{N}$ (2008:184-194) perkebunan yang dikembangkan adalah per-kebunan tebu, perkebunan tembakau, perkebunan karet, perkebunan kopi dan lain-lain. Perkebunan pada masa Hindia Belanda di Indonesia menjadi soko guru perekonomian. Upaya pengeksploitasian tidak hanya dilakukan di pulau Jawa saja melainkan sampai luar pulau Jawa, kesemuanya disesuaikan dengan tanaman komoditi yang ada di setiap daerah. Keadaan ini di dukung dengan sumber tenaga kerja murah dalam penggarapannya.
Keadaan ekonomi yang miskin semakin mendesak masyarakat mencari kerja tambahan dengan menjadi kuli kontrak diperkebunan Belanda di luar Jawa melalui jasa calo penyaluran tenaga kerja, Lurah maupun Kepala desa. Setelah mendapatkan upah, mereka oleh para mandor disuguhi dengan perjudian. Keberadaan akan judi ini membuat warga Indonesia atau kuli dari Jawa menjadi ketagihan dan selanjutnya para Kuli berhutang kepada Mandor. Adanya hutang dalam berjudi menjadikan para kuli ini terbebani hutang, dengan begitu maka mereka akan memperpanjang kontraknya untuk tetap menjadi kuli dengan upah yang murah. Semua itu merupakan taktik yang dilakukan oleh Belanda dengan maksud memperbanyak tenaga kerja murah bagi perkebunannya. Selama bekerja cuti bagi kuli merupakan hal yang istimewa, yang dianggap mereka sebagai cuti saat pembagian upah kerja yakni dua kali dalam sebulan (R.P. Suyono, 2005:103-112)

Buruh pada akhirnya bekerja demi upahan tidak demi pekerjaan, maupun demi pengembangan diri, sebab ada kondisi yang memaksa (dalam Umnia Labibah, 2004:30). Salah satu jenis pembagian kuli adalah kuli panggul. Panggul berarti membawa barang dengan dipanggul, sehingga cukup banyak barang yang mampu 
dibawa. Pekerjaan ini selain ditekuni oleh kaum laki-laki juga dilakukan oleh kaum perempuan. Pekerjaan ini banyak berkembang di pasar, karena di sana banyak yang membutuhkan jasa mereka. Karena tergolong kerja kasar, pekerjaan ini tidak memerlukan keahlian, serta tidak memerlukan adanya kualifikasi pendidikan tertentu. Bagi kuli khususnya kuli panggul permasalahan gaji tidak termuat dalam UMR (Upah Minimal Regional) dan UMK (Upah Minimal Kota).

Realitas memperkerjakan perempuan ini tidak bersumber pada kualitas sumber daya (human capital), namun memperkerjakan perempuan karena pertimbangan kesediaan dibayar murah disebabkan oleh lebihnya tenaga kerja dan tekanan kemiskinan menurut Tadjuddin (dalam Nursyahbani dkk, 2001:46). Penjelasan tersebut juga diutarakan oleh Jane C. Ollenburger dan Helen (1996:106) bahwa perempuan merupakan kelompok pekerja cadangan potensial yang bisa dimanipulasi oleh pemilik. Perempuan melakukan pekerjaan untuk upah yang lebih murah dari laki-laki. Menurut Ester Boserup (1984:69) banyak wanita yang bekerja sebagai buruh tani musiman, juga bersedia menerima pekerjaan lain, tentunya yang tidak membutuhkan ketrampilan. Perempuan bersedia menjalani pekerjaan kasar lainnya, semuanya berdasarkan pada kebutuhan akan keluarga.

\section{B. Perempuan}

Peribahasa orang Jawa menempatkan perempuan sebagai wanita "wanito" yang beratikan berani di tata. Menurut Arif Budiman (dalam Amin Yitno, DepDikBud, 1985: 3) mengungkapkan kebanyakan orang dalam membedakan antara laki-laki dan wanita tidak terbatas pada bentuk fisiknya. Dalam pandangan masyarakat laki-laki itu lebih rasional, aktif dan agresif, sedangkan wanita itu emosional, pasif dan submisif keseluruhan ini berdasar pembeda pada kejiwaan.

Zaitunnah Subhan (2004: 2) menjelaskan kata wanita dianggap berasal dari Bahasa Sangsekerta wan yang berarti nafsu, sedangkan dalam Bahasa Inggris perempuan atau wanita want dalam bentuk lampaunya wanted, yang menjadikan wanita sebagai Who is being wanted (seseorang yang dibutuhkan). Penempatan tersebut membuat perempuan ditakdirkan menjadi objek, dimiliki, dieksploitasi layaknya Alam yang diwujudkan dalam keajaiban ke-suburan perempuan Simone De Beauvoir (diterjemahkan Oleh Toni B. Febrianto, 2003:106).

Berdasarkan pengertian tersebut meletakan perempuan sebagai the second sex, seperti ungakapan orang Jawa yang proverbial swargo nunut, 
neroko katut, unggapan yang menguntungkan bagi kaum laki-laki. Hal senada juga diungkapkan Fauzi Ridjal dkk (1993: 50) Kebahagian atau penderitaan seorang perempuan tergantung dari kaum laki-laki (suami). Ungkapan Jawa tersebut selain menggambarkan ketergantungan perempuan, juga meng-hilangkan kebebasan kaum perempuan. Kebebasan yang dimaksud merujuk pada peran wanita dalam kemaslahatan Ihsanudin (dalam kajian Ilmi Magetan, 2012: 09). Peran perempuan dalam kehidupan bermasyarakat menjadi tersamar, sehingga muncul budaya patriarki didalamnya. Penjelasan mengenai hakikat perempuan, sebenarnya memiliki andil besar dalam kehidupan keluarga, masyarakat bahkan negara. Perempuan sebagai pedamping laki-laki memiliki peran dalam kesuksessannya, dengan cara memberikan suntikan moral dan memberikan semangat Umi Lestari (dalam majalah Mimbar Volume 307 Tahun 2012: 29). Uraian tersebut menguatkan jika ada laki-laki besar (sukses) pasti ada wanita hebat disampingnya.

Amien Yitno (dalam Soedarsono dkk, 1985: 9) mengemukakan jika ibu merupakan pusat, pengertian ini diperoleh dari kata matrifokal yang berasal dari penggabungan dua suku kata yakni matri dan fokal yang merupakan bahasa latin. Matri berasal dari kata mater yang berati ibu, sedangkan fokal berpangkal pada kata focus yang berarti pusat. Secara harfiah, matrifokal berati "ibu sebagai pusat" atau "berpusat pada ibu". Dari penjelasan tersebut, dapat disimpulkan jika perempuan atau seorang ibu merupakan inti ataupun pusat dalam kehidupan sehari-hari di suatu keluarga.

Menurut

Soenardjati-

Djajanegara (dalam Sugihastuti dan Itsna, 2007:300) salah satu sikap yang dilabelkan kepada gender feminis ialah sikap ketergantungan yang merupakan implikasi dari sikap vicarious (melakukan sesuatu bagai orang lain). Sifat ini dikarenakan perempuan di anggap lemah, dan bergantung pada laki laki atau suami. Dengan adanya pelebelan tersebut, maka menjadikan peran laki-laki sebagai superordinat dalam berbagai kehidupan. Menurut Collins, 1991 (dalam Irwan Abdullah, 2001: 110) per-bedaan perempuan dan laki-laki yang telah disosialisasikan dalam kehidupan berkeluarga, yang kemudian terrefleksikan dalam kecenderungan "menerima perintah" dan "memberi perintah".

$$
\text { Maria Etty }
$$

keberadaan perempuan pada masa lalu perannya hanya ditekankan pada peranan biologisnya, yakni mengandung, 
melahirkan, dan mengasuh anak. Peran yang diungkapkan tersebut tergolong peran tradisional yang dilakukan oleh perempuan. Keberadaan perempuan dalam sektor domestik sesuai dengan kata orang bahwa perempuan sebagai "ratu rumah tangga". Pasal 27 ayat 1 UUD 1945 hasil amandemen menjelaskan bahwa semua orang kedudukannya sama di mata hukum (Achie Sudiarti, 2007: 72). Namun dalam kenyataanya, sebagian masyarakat selalu menempatkan perempuan sebagai manusia kedua. Kenyataan ini merupakan fenomena diskriminasi gender. Menurut Ann Oakley (dalam Maria Etty, 2004:17) gender pada dasarnya adalah pembagian peran serta tanggung jawab, baik lelaki maupun perempuan, yang ditetapkan masyarakat secara sosial maupun kultural. Dengan begitu gender bukan sebagai kodrati yang diberikan Tuhan, melainkan hasil dari pembedaan yang dilakukan dalam perjalanan kehidupan. Pendapat tersebut juga di jelaskan Sugihastuti dan Itsna (2007:46) gender tidak diturunkan langsung melalui ciri biologis atau prakecenderungan seseorang untuk menjadi manusia dengan jenis tertentu. Gender juga bukan kepemilikan individu, melainkan pengaturan sosial dan setiap gender individu terbangun dalam orde sosial.
Abdul Haris dalam Irwan Abdullah (2006: 187) mengungkapkan gender sebagai hasil dari budaya terbangun atas dasar ide terhadap 2 kategori yaitu laki-laki dan perempuan dalam kehidupan bermasyarakat. Adanya hasil dari budaya, maka gender mengenal akan sistem hirarki yang bersifat oposisional dalam kelompokkelompok.

Studi mengenai analisis gender menimbulkan berbagai masalah, diantaranya: adanya marginalisasi ekonomi bagi perempuan (pemiskinan ekonomi). Terjadinya subordinasi yang menjadikan pendidikan serta keikutsertaan perempuan dalam sektor publik menjadi tidak penting. Terciptanya pelebelan yang negatif (stereotipe) bagi perempuan yang menjadikan diskriminasi. Kekerasan (violence) terhadap kaum perempuan baik kekerasan fisik, sampai kekerasan dalam bentuk yang lebih halus seperti pelecehan (sexualn harassment) dan penciptaan ketergantungan dijelaksan oleh Mansour Fakih (2008: 72-75). Peran gender yang melekat dari proses sosial dan kultural tersebut menjadikan tanggung jawab perempuan pada pekerjaan domestik yang lebih dominan/banyak dan lebih lama. Kondisi sekarang peranan perempuan tidak lagi hanya berkutat dengan peran tradisional saja, namun telah memiliki 
peran sosial yang menjadikan mereka mampu berkarir. Keikutseraan tersebut termasuk dalam hal ekonomi. Menurut Irwan Abdullah (2006: 13) gejala keterlibatan wanita di luar rumah menandakan bahwa perempuan telah berusaha merekontruksi sejarah hidupnya, dengan membangun identitas baru bagi dirinya, tidak hanya sebagai ibu/istri, tetapi juga sebagai pekerja dan wanita karier. Meski begitu, perempuan tidak bisa menanggalkan citranya sebagai ibu rumah tangga dan istri. Keikutsertaan tersebut membebaskan perempuan yang dulunya hanya berkutat pada sektor tradisional.

Adanya pembangunan dan modernisasi mulai merubah pola pikir serta memberi kesempatan bagi kaum perempuan, untuk memasuki sektor publik. Keterlibatan perempuan dalam pasar kerja lamban laun dapat memperbaiki status perempuan (Nursyahbani dkk ,2001: 44). Status perempuan yang dimaksud, jika sebelumnya seorang perempuan hanya berkutat dengan pe-kerjaan domestik (mengurus rumah tangga) sekarang telah mampu menjalankan peran sebagai seorang pekerja (angkatan kerja).

\section{Menurut Abdul Haris (dalam}

Irawan Abdullah, 2006: 185) menjelaskan wanita menjadi "pusat" perubahan sosial, ekonomi dan budaya.
Namun demikian, meskipun wanita mengambil posisi sebagai agent of change, mereka tetap berada di lapisan kedua dalam sistem hirarki sosialbudaya. Keterlibatan perempuan dalam upaya kegiatan ekonomi atau pemenuhan ekonomi keluarga, harus dibebani pula dengan melaksanakan kegiatan domestik sebagai seorang ibu maupun istri. Kedua kegiatan tersebut menunjukkan peran ganda atau rangkap bagi seorang perempuan. Kondisi tersebut diartikan Kamla Bhasin dan Nighat Said Khan (1999: 28) kaum perempuan selain menanggung beban pekerjaan dengan upah (sebagai bagian dari angkatan kerja) dan pekerjaan tanpa upah (dalam rumah tangga).

Terkait dengan bidang ekonomi, dalam tataran kehidupan orang Jawa dikenal kategori budaya tentang sumbangan suami maupun istri. Istilah yang digunakan adalah duit lanang dan duit wadon. Kedua istilah tersebut, penyebutan akan hasil kerja dari laki-laki maupun istri. Diantaranya, yang membedakan hanyalah pembagian dalam pengalokasian hasil kerja antar keduanya Pande Made Kutanegara (dalam Irwan Abdullah, 2006:200).

\section{Realitas Perempuan dalam Keluarga} dan Ekonomi

Pada masa lalu peran perempuan hanya ditekankan pada peran biologisnya, yakni untuk 
mengandung, melahirkan dan pengasuhan anak yang juga sering disebut dengan peran domestik. Kondisi ini terjadi setelah masuknya laki-laki dalam kelompok pihak perempuan setelah adanya perkawinan, maka lakilaki berkewajiban untuk memenuhi kebutuhan perempuan (keluarga). Sejak adanya perkawinan tersebut menjadikan adanya pembagian kerja menurut jenis kelamin, yang mana perempuan bertugas mengurus administrasi rumah tangga. Perempuan dalam masyarakat jawa selain dulunya hanya ditekankan dalam peran domestik, mereka juga ditempatkan sebagai the second human being yakni sebagai makhluk pelengkap setelah lakilaki. Sehingga menjadikan perempuan sebagai makluk yang lemah dan memerlukan adanya perlindungan baik secara fisik maupun psikologis.

Dalam Julian Clever (2002: 38) bagi perempuan, pekerjaan rumah tangga apapun bentuknya merupakan bagian penting dari peran gendernya. Seiring dengan perkembangan zaman serta gerak emansipasi perempuan pada saat ini, perempuan Indonesia tidak hanya sebagai korban, namun telah berani dalam membela kaumnya.

\section{Modernisasi}

dan

pembangunan telah mengantarkan perempuan untuk masuk ke dalam ranah ekonomi, hal ini terjadi karena penadapatan yang diperoleh suami di rasa tidak mencukupi akan kebutuahan rumah tangga.

Ken Suratiyah (dalam Irwan Abdullah, 2006: 227) perempuan yang terlibat dalam perekonomian ini adalah wanita pedesaan yang miskin, yang suaminya bekerja sebagai petani, buruh tani maupun buruh kasar yang lainnya. Perempuan sebagai pekerja merupakan bentuk tanggung jawab akan keberlangsungan ekonomi keluarga. Sekecil apapun pendapatan seorang perempuan tidak dapat dipandang sepele, karena dapat menopang kebutuhan dapur setiap hari.

Penjelasan Ken Suratiyah senada dengan Doni Rekro H (2001: 19) meski tugas domestik tetap menjadi urusan perempuan, namun bagi perempuan yang berasal dari keluarga berpenghasilan rendah, mereka sudah terbiasa mencari nafkah. Berbagai faktor yang menyebabkan perempuan melakukan peran yang kompleks karena tidak hanya melakukan kegiatan domestik, mereka juga harus terlibat dalam kehidupan ekonomi dalam upaya memenuhi ekonomi keluarga.

Keikutsertaan perempuan dalam upaya ekonomi keluaraga, menjadikan mereka secara tidak langsung menjalankan peran ganda, sebagai ibu rumah tangga (istri) serta menjadi pekerja informal. Keterlibatan 
perempuan tersebut juga atas persetujuan suami.

\section{Metode Penelitian}

Penelitian mengenai kuli panggul perempuan desa Selotinatah Kecamatan Ngariboyo Kabupaten Magetan merupakan studi kasus. Penelitian dilakukan selama kurang lebih 4 bulan yaitu bulan mei sampai dengan agustus 2012. Lokasi Penelitian berjarak 7 km dari Kabupaten Magetan.

Sumber data berupa Informal, Arsip dan Dokumen. Informasi dalam penelitian ini adalah perangkat desa Selotinatah, Ketua SPSI Cabang Pasar Sayur Magetan dan kuli Panggul perempuan Desa Selotinatah.Sedangkan Arsip merupakan buku yang relevan, Data BPS. Profil desa dan SPSI .

Validasi digunakan untuk menguji kebenaran data dengan menggunakan trianggulasi sumber penelitian. Hal ini mengarahkan agar di dalam pengumpulan data lebih menggunakan beragam sumber data yang berbeda. Artinya, sebuah data akan lebih berukur kebenarannya apabila dibandingkan dengan data sejenis yang diperoleh dari sumber lain yang berbeda. Kebergaman informasi yang didaptkan, maka akan banyak pendapat yang ada serta dapat memudahkan peneliti untuk memilah jawaban yang sama maupun tidak yang nantinya layak untuk dijadikan data.
Triangulasi tersebut dapat dilihat dalam bagan sebagai berikut:

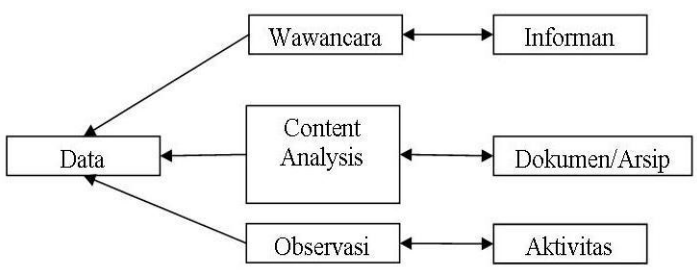

Bagan 3.2 . Bagan Trianggulasi Sumber Sumber : HB Sutopo, 2006: 49

Menurut Miles dan Huberman (dalam Basrowi dan Suwandi, 2008: 209) tehnik analisi data mencakup tiga kegiatan yang bersamaan yakni Reduksi Data (Reduction), Penyajian Data, dan Menarik Kesimpulan (Verifikasi).

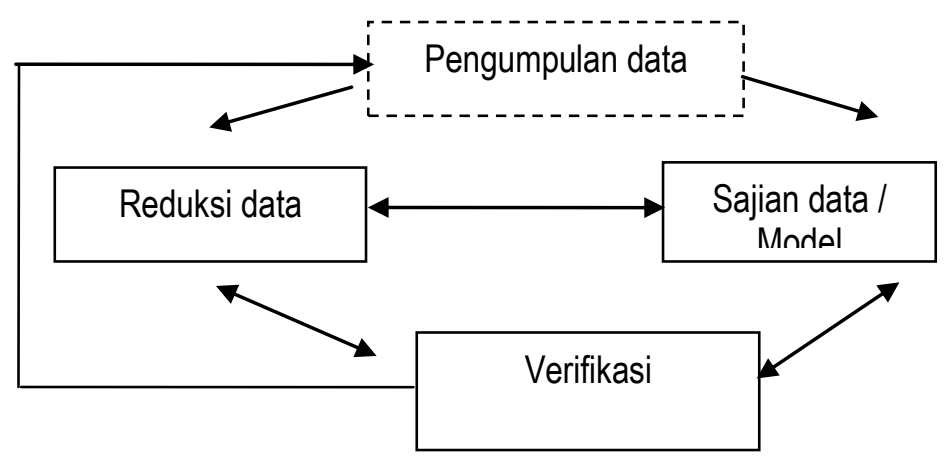

Bagan 3.3. Analisis Data Model Interaktif Sumber : Emzir, 2011: 134

\section{A. Seja}

Pekerjaan kuli ditekuni masyarakat Desa Selotinatah khususnya perempuan berawal dari tahun 1970-an, hal ini didasarkan karena di desa ini pada saat musim ketigo (Kemarau), setelah habis masa tanam dan panen tidak ada kegiatan pada bidang pertanian. Kondisi tersebut menjadikan para perempuan memutar otak untuk mencari pekerjaan lain (sumber pendapatan lain), karena 
kebutuhan hidup terus berlanjut. (Wawancara dengan Sarno, Tanggal 17 Mei 2012)

Pemilihan akan pekerjaan sebagai Kuli Panggul (Tenaga jasa) di pasar, awalnya belum menjadi prioritas atau tujuan. Saat itu mereka hanya berangkat ke pasar, karena mereka mengganggap entah apapun nanti pekerjaan yang dilakukan, pasti ada. Karena, pekerjaan yang dilakukan, menjadi masalah yang kesekian. Hal ini terjadi karena tuntutan perekonomian dalam pemenuhan kebutuhan rumah tangga. (Wawancara dengan Hartiah, Tanggal 26 Mei 2012)

Merujuk pada studi kasus mengenai keberdaan kuli panggul perempuan (Tenaga Jasa) yang banyak berasal dari desa Selotinatah, keterangan ini juga diperkuat oleh PLH Lurah Desa Selotinatah yakni Bapak Sarnu dan bapak Supangat selaku pengurus SPSI (Serikat Pekerja Seluruh Indonesia) cabang pasar sayur Kota Magetan.

Bekerja sebagai Kuli Panggul (Tenaga Jasa) juga terbagi atas sektor kerja (Sektor Beras, Sektor Sayuran dan Sektor Bahan Pokok) pembagian ini awalnya berlandaskan agar setiap pekerja dapat memperoleh hasil (uang). Seiring berjalannya waktu pembagian tempat itu menjadikan kedekatan antara kuli panggul (tenaga jasa) dengan para pemilik lapak (kios) (Wawancara dengan Lasmini, Tanggal 30 Mei 2012). Kedekatan ini menjadikan adanya kepercayaan dari pemilik kios dengan para kuli panggul (Tenaga Jasa) yang selain mengangkat barang para pembeli dari dalam pasar sampai ke parkiran, tentunya dengan bayaran yang tidak ditentukan dengan berat dan banyak barang yang diangkat, melainkan dengan keikhlasan para pembeli (Pengguna Jasa) itu sendiri. Tidak dipungkiri, dengan keuletan dan sikap baiknya terkadang para pemilik kios meminjamkan modal kepada kuli panggul (Tenaga Jasa) untuk mulai berdagang.

Pembagian ship berlaku pada sektor sayur, karena merupakan tempat penampungan sayur yang pertama sebelum sampai kepada pedagang yang tersebar di sekitaran pasar. Ship ini terbagi atas 2 jenis, yakni Ship pagi sekitar pukul 03.00 Wib (dini hari) sampai pukul 07.00 Wib dan Ship Siang sekitar Pukul 07.00 Wib sampai Pukul 16.00 Wib. Pada sektor Beras dan Bahan Pokok lainnya tidak adanya ship, karena jam bekerja mereka hampir bersamaan dengan bukanya pasar dan toko sekitar jam 09.00 Wib (Observasi Tanggal 20 Mei 2012).

Meski pekerjaan ini terlihat remeh, namun hasil yang di dapat untuk biaya hidup di Magetan 
khususnya desa Selotintah bisa dikatakan cukup, dengan penghasilan rata-rata Rp.50.000,00, perhari. Namun, terkadang juga sampai Rp.70.000,00 perhari. Meski, begitu dengan penghasilan uang memang cukup untuk biaya hidup. Namun, hal ini terkadang kurang saat ada acara (Gawe) di tetangga (seperti nikahan dan sunatan). Selain dari kuli (Tenaga Jasa) mereka juga mendapatkan hasil dari petani maupun buruh petani. Dengan begitu, maka menjadikan keikutsertaan dari para sanak saudara bahkan ada yang di antara anak mereka yang mengikuti jejak orang tuanya sebagai kuli panggul (Tenaga Jasa) (Wawancara dengan Winarsih, Tanggal 03 Juni 2012). Ukuran pendapatan yang diperoleh kuli panggul ini, dijadikan kebijakan dalam penentuan UMK (Upah Minimal Kota) (Wawancara dengan Supangat, 05 Juni 2012)

Ada dari beberapa orang yang memilih kuli panggul (Tenaga Jasa) sebagai pekerjaannya, karena mereka masih ingin tetap di Jawa seperti kata pepatah "Lebih baik hujan batu di negeri sendiri dari pada hujan emas di negeri orang", apapun pekerjaan yang di kerjakan asal bisa buat makan dan masih kumpul bersama-sama keluarga akan mereka jalani (Wawancara dengan Sarkiyem, Tanggal 03 Juni 2012).
Di pasar sayur kota Magetan, yang kebanyakan di dominasi dari Desa Selotinatah khususnya Dusun Banaran maka mereka yang bekerja sebagai kuli panggul (Tenaga Jasa), ada yang berangkat diantar oleh suami yang kebetulan suaminya juga sebagi kuli dan ship yang sama, ada juga yang berangkat besama-sama.

\section{B. Faktor-faktor kaum perempuan Desa}

\section{Selotinatah menjadi Kuli Panggul.}

Faktor ataupun alasan para perempuan Desa Selotinatah bekerja menjadi Kuli Panggul (Tenaga Jasa) dari hasil wawancara dapat diketahui :

1) Berawal dari minimnya pekerjaan setelah masa panen dan tanam, sehingga mereka (para perempuan) Desa Selotinatah mulai memikirkan cara lain untuk mendapatkan hasil karena kebutuhan rumah tangga yang setiap hari. (Wawancara dengan Sadiyem, Tanggal 28 Mei 2012)

2) Dengan kondisi tersebut, dengan minimnya pendidikan dan kemampuan yang ada, maka mereka memilih pekerjaan yang mengandalkan otot serta tanpa adanya prosedur yang bertele-tele. (Wawancara dengan Warsini, Tanggal 28 Mei 2012)

3) Ada dari beberapa yang menjadikan pekerjaan sebagai Kuli Panggul ini jadi pekerjaan yang utama, karena 
tidak memiliki lahan pertanian di desa.

4) Adanya ketertarikan menjadi kuli, karena mengikuti jejak saudara/ibu yang penghasilannya dapat membantu dalam perekonomian keluaraga (Hartiyah, Tanggal 26 Mei 2012)

\section{Kehidupan Sehari-Hari Kuli Panggul}

\section{Perempuan}

Kehidupan

sehari-hari

seseorang, terhubung akan masalah interaksi dan komunikasi. Terkadang dengan jenis pekerjaan tertentu, akan mempengaruhi kedekatan (tali persaudaraan) dengan tetangga. Namun, hal ini tidak menjadi masalah bagi para pekerja kuli panggul perempuan Desa Selotinatah, meski pekerjaan yang mereka lakukan tergolong membutuhkan waktu yang cukup lama. Kehidupan sehari-hari yang terkait dengan interaksi tidak hanya dengan keluarga, tetangga dan masyarakat desa setempat dapat berjalan dengan baik. Komunikasi yang terjalin tentunya mengekor pada sektor dan jam kerja yang ada.

Pekerjaan sebagai kuli panggul dengan kondisi jam yang ada, kuli panggul perempuan masih bisa mengurus rumah tangga. Sedangkan, dengan masyarakat terjalin dengan adanya kegiatan setiap minggunya arisan dan yasinan (Wawancara dengan
Hartiyah, Tanggal 26 Mei 2012). Sedangkan, dengan para kuli panggul sendiri adanya kegiatan arisan selain itu juga pada mereka (Kuli Panggul/Tenaga Jasa) biasanya bercengkrama saat rehat maupun menunggu para pembeli yang membutuhkan jasa mereka (Observasi Tanggal 20 Mei 2012).

Sebelum adanya pendataan akan pekerja jasa baik Kuli Panggul maupun pekerja jasa yang lain (Ojek) di seluruh Kota Magetan. Pendataan ini mulai dilakukan kurang lebih sekitar tahun 1978 (Wawancara dengan Supangat, Tanggal 05 Juni 2012). Selang beberapa Tahun kemudian, sekitar tahun 1988 mengawali adanya kerja sama dengan pihak Jamsostek, kesepakatan ini menghasilkan dua premi yaitu: Jaminan Kecelakaan Kerja dan Jaminan Kematian. Selain dengan Jamsostek, SPSI cabang Pasar Sayur Magetan juga bekerjasama dengan Pedagang besar (Tengkulak) berhubungan dengan kuli panggul (tenaga jasa) yang mengakuti barangnya dari truk.

Untuk saat ini jumlah kuli panggul (Tenaga Jasa) di pasar sayur kota Magetan, perempuan berjumlah 275 Orang dan Laki-laki 160 Orang. 
Tabel 4.8. Daftar Ketua

Kelompok Anggota Kuli Panggul

\begin{tabular}{|c|l|c|c|}
\hline $\begin{array}{c}\text { N } \\
\text { o }\end{array}$ & Nama & $\begin{array}{c}\text { Jumlah } \\
\text { Anggota }\end{array}$ & Alamat \\
\hline 1 & Sakiyah & 33 & Selotinatah \\
\hline 2 & Tukini & 20 & Balegondo \\
\hline 3 & Karmi & 25 & Baleasri \\
\hline 4 & Murweti & 17 & Selotinatah \\
\hline 5 & Sarinem & 33 & Selotinatah \\
\hline 6 & Juminem & 28 & Selotinatah \\
\hline 7 & Suwuh & 18 & Selotinatah \\
\hline 8 & Rusmini & 43 & Selotinatah \\
\hline 9 & Riyem & 30 & Selotinatah \\
\hline 1 & \multirow{2}{*}{ Sumini } & 27 & Selotinatah \\
0 & & & \\
\hline
\end{tabular}

Sumber : Data DPC SPSI Pasar Sayur

Magetan tahun 2012

Adanya pendataan kuli panggul

tersebut, sejumlah (Pekerja Jasa)

berhak mendapatkan Jamsostek, selain itu bagi Para Ojek yang tergabung dalam SPSI (Serikat Pekerja Seluruh Indonesia) daerah Magetan umumnya memperoleh kemudahan jika ada operasi polisi. Keanggotaan ini dibuktikan dengan adanya kartu anggota yang berlaku selama 2 Tahun dan setelahnya di-lakukan pembaharuan kartu anggota (Wawancara dengan Supangat, Tanggal 05 Juni 2012).

Jumlah kuli panggul (Tenaga Jasa) yang tidak sedikit membuat petugas SPSI (Serikat Pekerja Seluruh Indonesia) khusus pasar sayur Magetan kesulitan dalam mengorganisir dan menyampaikan informasi yang terkait. Pembentukan kelompok dalam masingmasing sektor (Sektor Beras, Sektor
Sayuran dan Sektor Bahan Pokok) dengan estimasi satu kelompok ada 9 sampai 41 orang/anggota. Setiap kelompok tentu ada ketua dan bendahara, yang penunjukkannya melalui pemilihan (musyawarah kelompok). Dengan adanya ketua ini, maka pengurus SPSI (Serikat Pekerja Seluruh Indonesia) khusus cabang pasar sayur Magetan mudah dalam pengaturan dan penyampain informasi.

Kegiatan yang dilaksanakan oleh SPSI (Serikat Pekerja Seluruh Indonesia) khusus pasar sayur Magetan biasanya tanggal 02 setiap bulannya ada kegiatan arisan dan pembayaran iuran setiap individu kuli panggul (Tenaga Jasa), yang terwakili oleh masing-masing ketua kelompok, selain itu juga ada kegiatan Jum'at bersih.

Pelaksanaan kegiatan ini, dimakssudkan untuk menumbuhkan rasa kebersamaan dalam bekerja, sehingga tidak menimbulkan adanya persaingan dalam melaksanakan pekerjaan.

Untuk sekarang pekerjaan sebagai kuli panggul atau (tenaga jasa) tidak ada lowongan, dengan pertimbangan jumlah pekerja dengan sektor kerja yang ada (Wawancara dengan Supangat, Tanggal 05 Juni 2012). Meski begitu, jika mereka ingin (para pencari kerja) untuk melakukan pekerjaan ini mereka jika ada yang 
digantikan seseorang dari sektor tertentu. Karena pasar bukan merupakan pabrik, maka dari dinas pasar tidak bisa memberikan pesangon (Wawancara dengan Hartiyah, Tanggal 26 Mei 2012). Bagi para pengganti memberikan tanda terima kasih kepada orang yang digantikan dengan memberikan sejumlah uang, yang nominalnya disesuaikan dengan kelas.

Tabel 4.9. Rincian Tanda Terima Kasih (Tali Asih)

\begin{tabular}{|c|c|c|}
\hline No & Kelas & Jumlah (Rp) \\
\hline 1 & Kelas I & $10.000 .000-$ \\
& (Kuli Laki- & 15.000 .000 \\
& Laki) & \\
\hline 2 & Kelas II & $5.000 .000-$ \\
& & 7.000 .000 \\
\hline 3 & Kelas III & 3.500 .000 \\
\hline
\end{tabular}

Sumber : Wawancara dengan Beberapa Kuli Panggul

Mengenai pemberian uang (tanda terima kasih) tersebut tidak menjadi aturan yang tertulis, namun sudah menjadi kebiasaan. Pendapat senada juga disampaikan oleh Sarno, Eni Muslikah dan Supangat.

\section{Pembahasan}

Sejarah keberadaan kuli panggul perempuan di Desa Selotinatah tidak lepas dari ketersedian pekerjaan, terutama setelah masa tanam dan panen di wilayah pedesaan. Pada kedua masa tersebut banyak memerlukan tenaga kerja, namun setelah itu banyak masyarakat yang mengganggur. Pekerjaan kuli adalah tenaga jasa, yang tergolong sebagai pekerjaan kasar. Kerja yang mereka lakukan (bagi perempuan) jika melihat akan fisik, sebenarnya mereka sama dengan perempuan yang lainya. Ada diantara mereka yang berperawakan kecil, sedang dan subur. Namun, keadaan fisik tidak menjadi penghalang bagi perempuan desa Selotinatah untuk menjalaninya, karena motivasi mereka untuk bertanggung jawab akan ekonomi keluarganya menjadi kekuatan tersendiri dalam menjalani pekerjaan.

Penduduk di pedesaan padau mumnya memang banyak yang bekerja lebih dari satu jenis pekerjaan.Kondisi ini terjadi jika hasil dari pekerjaan utama tidak mencukupi. Kegiatan nonpertanain yang dapat dikerjakan antara lain (termasuk buruh industri, buruh kegiatan industri rumah tangga/kerajinan, dagang dan buruh nonpertanian bangunan, pekerja angkutan, jasa, mencari barang di alam bebas dan kegiatan kegiatan sektor formal) Mubyarto (1985:153-164).

Pengalihan kegiatan/tenaga selama menunggu masa panen ada sebagian masyarakat yang melakukan kegiatan mengrajin. Namun, kerajinan yang dibuat tentunya disesuaikan dengan identitas daerahnya. Aspek kesejarahan kuli panggul terkait dengan 
hukum sebab-akibat.Hal ini terjadi karena adanya sebab kebutuhan ekonomi maka menyebabkan pekerjaan itu ada atau sebaliknya.Menurut Irwan Abdullah (2001: 158-159) alasan perempuan kepasar, diantaranya: a) posisi perempuan lemah dalam bidang pertanian; dan, b) tekanan ekonomi rumah tangga tani.

Pendapat tersebut menguatkan mengenai alasan mengenai awal mula keberadaan kuli panggul/tenaga jasa di pasar sayur Kota Magetan.Selain daripada alasan tersebut, faktor pendidikan juga menjadi salah satu faktor perempuan desa Selotinatah menjadi tenaga jasa, kebanyakan dari yang bekerja sebagi kuli panggul/tenaga jasa hanyalah lulusan SD bahkan ada yang tidak sekolah (lihat tabel 4.3. Jumlah Penduduk berdasarkan tingkat Pendidikan) dengan tingkat pendidikan yang minim serta tidak memiliki ketrampilan tertentu, menjadikan mereka memilih pekerjaan yang tidak membutuhkan ketrampilan serta standrat pendidikan tertentu. Faktor topografi desa Selotinatah yang berada di dataran tinggi/pegunungan dengan keadaan sawah yang merupakan tadah hujan maka tanamannya (Sumber Daya Alam) disesuaikan dengan ketersediaan air (lihat tabel 4.6. Sumber Daya Alam) juga menjadi salah satu faktor perempuan desa Selotinatah untuk bekerja sebagai kuli panggul/tenaga jasa di pasar sayur kota Magetan yang berjarak sekitar 7,5 km dari desa Selotinatah.

Asal-asul atau kesejarahanan pekerjaan kuli panggul dijalani perempuan Desa Selotinatah terkait dengan alasan ataupun faktor-faktor yang menjadikan perempuan desa Selotinatah memilih pekerjaan sebagai kuli panggul (tenaga jasa). Tentang bagaimana ataupun siapa yang pertama kali yang membuka kesempatan kerja ini, dari beberapa hasil wawancara tidak diketahui secara pasti .Penjelasan mengenai alasan, akan terhubung juga dengan kemampuan atau kreativitas, selain ketiadaan modal untuk melakukan usaha. Keterbatasan dan ketiadaan modal ini membawa meraka (para perempuan) untuk melakukan pekerjaan yang ada, asalkan mendapatkan hasil/uang.

Kesengajaan yang dulunya dilakukan perempuan Desa Selotinatah pergi ke pasar tanpa rancangan itu, menjadi pintu pembuka pekerjaan baru bagi warga Selotinatah khususnya perempuan.Meski tanpa diketahui secara pasti siapa yang memulai pekerjaan ini.Namun, untuk sekarang ini cukup banyak perempuan Desa Selotintah yang bekerja sebagai kuli panggul (tenaga jasa).Selain itu mulainya atau awal pekerjaan inipun juga tidak diketahui 
secara pasti.Dari beberapa hasil wawancara ada yang telah bekerja selama 30 tahunan, yang hal ini menjadikan pekerjaan sebagai kuli panggul (Tenaga Jasa) membudaya. Karena dari penelitian, ada yang satu keluarga yang terdiri atas Bibi (Kakaknya Ibu) , Ibu (Adik) dan Anak (Keponakan). Selain karena faktor penghasilan dan kemampuan yang terbatas, bagi mereka tak ada salahnya berbagi pekerjaan dengan saudara, karena bagi mereka (perempuan) rejeki sudah ada yang mengatur.Kejadianini yang menjadikanpekerjaansebagaikulipanggul (TenagaJasa) mampumembudaya (turuntemurun).Pembagian sektor kerja terjadi secara alamiah, yang kemudian menjadi aturan yang tidak tertulis namun menjadi kesepakatan bersama.Untuk sekarang bisa dikatakan kesempatan pekerjaan ini sudah tidak ada meski pasar merupakan area publik. Keputusan atupun kebijakan ini dilakukan karena pertimbangan akan hasil. Sebagai perumpamaan nasi sepiring yang cukup dimakan berempat harus dimakan berlima ataupun berenam tentu tidak akan kenyang. Alasan inilah yang mendasari kebijakan tersebut.

Kebijakan tersebut, jika ditelaah memang bisa dikatakan baik.Sebagai pertimbangan tidak apa-apa sedikit yang penting cukup. Meski begitu jika ada salahs atu yang cuti atau izin adak epentingan, maka bolehdigantikan orang lain dengan persyaratan membawa kartu anggota orang yang digantikan. Pembawaan akan kartu ini juga bertujuan agar tidak terjadi kesalah fahaman akan sesama kuli panggul. Kuli panggul ini juga ada pendataan anggotanya. Manfaat pendataan selain mudah dalam pengorganisasian dan penyampain informasi serta terkait sikap dalam kinerja Kuli panggul (tenagajasa).Dalam keseharian bekerja para kuli panggul (tenaga jasa) ada juga penilainnya (rapot), penilaian ini dilakukan sesama kelompok atupun pedagang yang biasanya menjadi tempat mangkal (area) dan tempat peristirahatan bagi kuli panggul.Adanyapenilaianbertujuan, jika ada keluhan dari para pedagang besa rmengenai sikap maka kelompok dan selanjutnya SPSI Cabang Pasar Sayur Magetan dapat mengatasinya (Wawancara denganSupangat, Tanggal 05 Juni 2012).Keberangkatannya kepasar ada beberapa yang diantar oleh suaminya, yang kebetulan juga bekerja di bidang yang sama. Namun, ada diantara mereka yang menggunakan angkutan desa (AngkotDes).

Keterlibatan perempuan dalam ekonomi rumah tangga, sejalan dengan menurunnya peranan perempuan itu sendiri dalam sektor pertanian dalam per-ekonomian desa.Sementara, 
kebutuhan uang tunai sehari-hari terus diperlukan (Irwan Abdullah, 2001: 145).Pendapat tersebut, sesuai dengan alasan yang mendasari perempuan Desa Selotinatah bekerja sebagai kuli panggul, selain dari sektor pertanian.Merujukpadafactoratau alasan yang mendasari para kaum perempuan desa Selotinatah untuk menjalani pekerjaan sebagai kuli panggul (Tenaga Jasa), bertolak dari kebutuhan yang setiap hari. Ada beberapa faktor yang menjadikan para perempuan Desa Selotinatah memilih bekerja menjadi kuli panggul (Tenaga Jasa) :

1. Mengisi waktul uang selepas masa panen. Diketahui bahwa pekerjaan di desa dalam bidang pertanian sedikit yang tersedia dan sedikit membutuhkan tenaga jasa, dengan alasan tersebut para perempuan dari desa Selotinatah memutar pikiran untuk mencari pekerjaan lain (kesibukan). Awalnya mereka hanya berangkat kepasar, tanpa memikirkan pekerjaan apa yang akan mereka lakukan.

2. Denganpekerjaan yang ada, mereka (kuli panggul/tenaga jasa) tetap ingin menjadi Ibu rumah tangga. Adanya ke dua fungsi yang tetap ingin mereka lakukan, membuktikan bahwa mereka (kuli panggul/tenaga jasa) memiliki peran ganda, yang dilakukan dengan rasa tanggung jawab.

3. Namun, ada di antarameraka (kuli panggul/tenaga jasa) yang menjadikan pekerjaan tersebut, menjadi pekerjaan yang utama. Disebabkan karena tidak memiliki lahan persawahan dan ketiadaan modal untuk melakukan pekerjaan lain sebagai contoh berdagang.

Semula mereka pergi ke pasar tanpa adanya pekerjaan yang jelas akan mereka lakukan, ternyata membawa keberkahan yang lain bagi mereka para pelaku tenaga jasa (kuli panggul). Seiringwaktu, yang bermulasebagaiupayamengisiwaktu luang tersebut para kuli perempuan (Tenaga Jasa) secara tidak langsung telah menjadi pekerjaan yang utama bagi beberapa orang.Keinginan mereka (para perempuan) untuk bekerja sebagai tenaga jasa ternyata di sambut baik oleh para suami, selain karena kebutuhan juga karena keinginan yang kuat itu sendiri dari seorang istri.

Membahas mengenai pekerjaan ini, maka akan terlintas jika ada di desa lain yang lebih memilihsebagai TKW (Tenaga Kerja Wanita) yang sebagai pertimbangan adalah hasil. Keadaan ini berbeda dengan pendapat perempuan yang bekerja sebagai kuli panggul (Tenaga Jasa), bagi mereka hasil sedikit namun masih bias tetap bersama-sama 
anak/keluarga.Keberadaan akan kuli panggul ternyata juga menjadi unsur pendukung akan keberadaan pasar tradisonal sendiri. Walau terkadang, adanya kuli tersebut menjadi pemandangan yang kurang menyenangkan bagi sebagian pengunjung.Padahal keberadaan mereka juga sangat dibutuhkan, tidak hanya bagi pembeli tapi juga para pedagang.

Permasalahan dengan mulai maraknya pasar moderent yang menjadikan geliat pasar tradional menurun, juga berpengaruh pada keadaan kuli panggul itu sendiri. Keterlibatan perempuan akan kehidupan ekonomi menjadikan mereka menjalani dua peran "beban ganda" dalam kesehariannya, yakni peran sebagai ibu rumah tangga "ratu rumah tangga" serta tenaga kerja upahan.Ken Suratiyah (dalam Irwan Abdullah 2006:224) peran ganda dalam kehidupan wanita pedesaan yakni tugas mencari nafkah serta tugas tanggung jawab atas kegiatan rumah tangga sehari-hari.

Kehidupan sehari-hari seseorang terkait dengan interaksi dan hubungan antar keluarga dan sesama tetangga (masalah kehidupan Sosial), interaksi sosial merupakan proses sosial dan merupakan syarat utama terjadinya aktivitas-aktivitas

sosial.
Interaksisebagai proses sosial juga adasyarat-syarat dalam ter-jadinya, yakni : 1) Adanya kontak sosial dan 2) adanya komunikasi (Soerjono Soekanto, 2004: 61,64).Komunikasi menurut Hovland, dkk (dalam Arni Muhammad,2004: 2,184) menjelaskan komunikasi merupakan proses individu mengirim stimulus yang biasanya dalam bentuk verbal untuk mengubah tingkah laku orang lain, , komunikasi dalam kelompok kecil seringdigunakan dalam pembuatan keputusan dan pemecahan masalah yang terjadi dalam kelompok.

Alasan kehidupan sosial menjadi pembahasan berdasarkan bahwa manusia itu adalah makhluk sosial/makhluk yang saling membutuhkan. Masalah sosial yang dibahas terkait dengan interaksi.Dengan jam kerjapara kuli panggul perempuan (Tenaga Jasa) yang tidak sebentar, maka memungkinkan akan mempengaruhi hubungan dan interaksi tersebut. Meskidenganinterval jam yang berbeda antar sektor di pasar Sayur Kota Magetan, ternyata tidak menjadikan interaksi para kuli panggul (TenagaJasa) dengan keluarga maupun masyarakat tetap berjalan dengan baik/kondisi sewajarnya. Hal ini dikarenakan, adanya pembagian jam kerja antar sektor tersebut serta pergantian jam kerja bagi kuli panggul (tenaga jasa) pada setiap minggu maupun bulan.Mengenai 
interaksi sesama keluarga, para pekerja perempuan ini masih bisa mengurus keluarganya.Mengenai interaksi antar tetangga (bagi kaum perempuannya), dapat diatasi dengan adanya kegiatan yasinan dan arisan setiap minggunya di Desa Selotinatah. Adanya kegiatan rutin ini, tentu akan memangkas misskomunikasi antar warga khususnya para perempuannya selama mereka bekerja.

Membahas lebih lanjut tentang interaksi para kuli panggul (dengan keluarganya, maka dapat dijelaskan dengan merujuk pada tempat kerja (sektor). Sektor Beras, Sektor Sayuran dan Sektor Bahan Pokok. Diantara masing-masing sektor yang adatersebut, maka waktu kebersamaan mereka dengan keluarga juga akan berbeda. Bagi para kuli yang bekerja pada sektor sayuran (pasar penampungan) kebersamaan mereka dengan keluarga terjadi dari mulai pukul tujuh pagi, dengan begitu mereka masih bisa menyiapakan apa keperluan yang dibutuhkan anaknya saat malam hari. Menyangkut pekerjaan rumah tanga yang lainnya dapat dilakukan setelah pulang dari kerja pagi harinya. Sedangkan, bagi yang bekerja pada sektor beras dan sektor bahan pokok dapat melakukan pekerjaannya sebelum berangkat kerja. Bagi yang mereka bekerja pada sektor beras dan bahan pokok masa kerja mereka sekitar jam Sembilan pagi sampai jam empat sore. Interaksi dengan para anggota kuli itu sendiri terjalin setiap bulannya dengan kegiatan arisan setiap tanggal dua. Kedekatan mereka juga terjalin dengan adanya kerja bakti setiap minggunya yakni pada hari jum'at.Adanya kedua kegiatan tersebut secara tidak langsung menjadikan interaksi antar anggota kuli itu sendiri. Kondisi jam kerja tersebut, ternyata juga tidak berpengaruh akan pola interaksi serta kedekatan hubungan antar pekerja kuli panggul perempuan dengan keluarga, masyarakat dan sesama pekerja kuli panggul tersebut.

\section{Penutup}

\section{A. Simpulan}

Sejarah awal kuli panggul perempuan di Desa SelotinatahKabupaten Magetan sejak tahun 1970-an, namun tidak diketahui secara pasti siapa yang memulai.Setelah masa tanam danmenunggu masa panen, tenaga yang di-butuhkan dalam sektor pertanian sedikit sehingga banyak waktu luang. Saat seperti itu, kaum perempuan Desa Selotinah berangkat kepasar tanpa mem-perdulikan pekerjaan apa nantinya yang akan dilakukan disana, namun ternyata hal itu membuka peluang kerja baru di pasar sebagai kuli panggul. 
Faktor yang mendasari para perempuan memilih bekerja sebagai kuli karena habis masa panen, tidak ada pekerjaan dalam sektor pertanian, prosedur menjadi kuli panggul tidak berbelit-belit. Selain itu, pekerjaan ini sudah ada yang mengawali seperti ibuataupun saudara yang lain serta ingin membantu suami dalam perekonomian keluarga dengan tidak meninggalkan pekerjaan rumah tangga.

Kehidupan sehari-hari kuli panggul perempuan di keluarga tetapdapat berjalan dengan baik.Mereka bekerja atas persetujuan para suami dan masih tetapbisa mengurus keperluan anak dan keluarga.Hubungan dengan tetangga tetapterjalin dengan adanya kegiatan arisan dan yasinan.Begitupun dengan sesama kuli juga terjalin dari organisasi dalam setiap sektor dan juga seluruh kuli juga dengan kegiatan arisan.

\section{B. Saran}

Berdasarkan hasil penelitian di atas, maka penulis memberikan saran Bagi Pendidikan Sejarah dengan keterbatasan data yang didapatkan peneliti, diperlukan adanya penelitian yang mendalam terkait dengan sejarah kuli panggul perempuan di pasar sayur Kota Magetan baik terkait dengan masalah sosial, ekonomi maupun kesejarahannya.Pemangku kebijakan melihat dari banyaknya kuli panggul perempuan yang berasal dari Desa Selotinatah, maka diperlukan adanya peninjauan terhadap masyarakat Desa tersebut. Mendayagunakan masyarkat dalam bentuk ekonomi mandiri, seperti peminjaman modal.

\section{Daftar Pustaka}

Abdul Haris._.."Mobilitas Angkatan Kerja Wanita Indonesia ke Luar Negeri".2006. Irwan Abdullah Sangkan Paran Gender. Yogyakarta : Pustaka Pelajar Cetakan ke III

Abraham N, Dkk. 2009. Ilmu Sosial dan Budaya Dasar. Magetan : Le_Swastika

Achie Sudiarti. 2007. Bahan Ajar Tentang Hak Perempuan. Jakarta: Yayasan Obrol Indonesia

Amien Yitno.1985."Gejala Matrifokalitas di Masyarakat Jawa". (Soedarsono, dkk). 1985. Wanita, Kekuasaan dan Kejahatan: Beberapa Aspek Kebudayaan Jawa. Jakarta : Proyek Penelitian dan Pengkajian Kebudayaan Nusantara (Javanologi) Direktorat Jenderal Kebudayaan Departemen Pendidikan dan Kebudayaan

Arni Muhammad. 2004. Komunikasi Organisasi.Jakarta : Bumi Aksara

Barthos, Basir. 2001. Manajemen Sumber Daya Manusia. Jakarta : Bumi Aksara

Baseruf, Ester.1984. Peranan Wanita Dalam Perkembangan Ekonomi. Jakarta : Yayasan Harapan Indonesia

Basrowi dan Suwandi. 2008. Memahami Penelitian Kualitatif. Jakarta : Rineka Cipta

Beauviour, De Simone (Diterjemahkan Oleh Toni B. Febrianto). 2003. Secand Sex Fakta dan Mitos. Surabaya : Pustaka Promethea

Bhasin, Kmala \& Khan S Nighat. 1999. Persoalan Pokok Mengenai FEMINISME DAN 
RELEVANSINYA.Jakarta:

Gramedia Pustaka Utama

Breman, Jan. 1986. Penguasaan Tanah dan Tenaga Kerja Jawa di Masa Kolonial. Jakarta :LP3S

Doni Rekro Harijani. 2001. Etos Kerja Perempuan Desa Realisasi Kemandirian dan Produktivitas Ekonomi. Yogyakarta : Philosophy press

Emzir. 2011. Metodologi Penelitian Kualitatif Analisis Data. Jakarta : Rajawali Press

Fauzi Ridjal, dkk. 1993. Dinamika Gerakan Perempuan di Indonesia. Yogyakarta: PT. Tiara Wacana Yogya

Irwan Abdullah. 2001. Seks, Gender \& Reproduksi Kekuasaan. Yogyakarta : Tarawang Pres

Kansil, C.S.T \& Chriestin. 2004. Pemerintahan Daerah Di Indonesia Hukum Administrasi Daerah. Jakarta : Sinar Grafika

Ken Suratiyah._. "Pengorbanan Wanita Pekerja Industri". . Irwan Abdullah Sangkan Paran Gender. Yogyakarta : Pustaka Pelajar Cetakan ke III

Majalah Bening (Ihsanudin). 2012. Jejak Perempuan di Zaman Rasulullah. Magetan : ILMI cabang Magetan

Majalah Mimbar No. 307 (Umi Lestari). 2012. Ulama Sang pencerah Ketika Bunga-bunga Berguguran. Surabaya : Kantor Wilayah Kemenag Provinsi Jatim

Mansour Fakih. 2008. Analisis Gender dan Transformasi Sosial. Yogyakarta : Pustaka Pelajar

Maria Etty. 2004. Perempuan Memutus Mata Rantai Asimetri. Jakarta : Grasindo

Marwati Djoned dan Nugraho, N. 2008. Sejarah Nasional Indonesia V Zaman Kebangkitan Nasional dan Masa Republik Indonesia (+1900 1942) (Edisi Pemutahiran). Jakarta : Balai Pustaka

Mosse, Julia Cleves . 2002. Gender dan Pembangunan. Yogyakarta: RIFKA ANISSA Women's Crisis Center
Mubyarto. 1951. Peluang Kerja dan Berusaha di Pedesaan. Yogyakarta: BPFE UGM

Nursyahbani, dkk. 2001. Potret Perempuan Tinjauan Politik, Ekonomi, Hukum di Zaman Orde Baru. Yogyakarta : Pustaka Pelajar

Ollenburger, Jane. 1996. Sosiologi Wanita. Jakarta : PT. Rineka Cipta

Pande Made Kutanegara._. "Perdagangan: Kosmologi dan Konstruksi"dunia wanita". . Irwan Abdullah Sangkan Paran Gender. Yogyakarta : Pustaka Pelajar Cetakan ke III

R. Bintarto. 1984. Interaksi Desa-Kota dan Permasalahnnya: Jakarta: Ghalia Indonesia.

R. P. Suyono. 2005. Seks dan Kekerasan pada Zaman Kolonial Penelusuran Kepustakaan Sejarah. Jakarta : Gramedia

Ravik Karsidi. 2003. Dari Petani ke Pengrajin Sebuah Transformasi Pekerjaan. Surakarta : Pustaka Cakra

Soerjono Soekanto . 2004. Sosiologi Suatu Pengantar. Jakarta : PT Raja Grafindo Persada 2001. Sosiologi Suatu Pengantar. Jakarta : PT. Raja Grafindo Persada

Sugihastuti dan Itsna .2007. Gender \& Inferioritas Perempuan Praktik Kritik Sastra Feminis. Yogyakarta: Pustaka Pelajar

Suhartono. 1991. Apanage \& Bekel Perubahan Sosial di Pedesaan Surakarata 1830-1920. Yogyakarta: PT Tiara Wacana Yogya

Sutopo. 2006. Metode Penelitian Kualitatif.

Surakarta : Universitas Sebelas Maret

Tadjuddin Noer Effendi. 2001. "Peran Perempuan Dalam Pembangunan Ekonomi". (Nursyahbani, dkk). 2001. Potret Perempuan Tinjauan Politik, Ekonomi, Hukum di Zaman Orde Baru. Yogyakarta : Pustaka Pelajar

Team. 2003. Undang-Undang Republik Indonesia No 13 Tahun 2003 tentang Ketenagakerjaan.

Team. 2006. Peraturan Pelaksanaan Pemerintahan Daerah Pedoman 
126 | JURNAL AGASTYA VOL 03 NO 01 JANUARI 2013

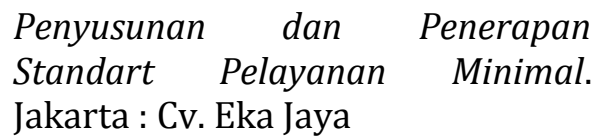

Umnia Labibah. 2004. Wahyu Pembebasan :

Relasi Buruh Majikan. Yogyakarta :

Pustaka Alief

Zaitunah Subhan. 2004.Kodrat Perempuan

Takdir atau Mitos? Yogyakarta: PT LKIS

Pelangi Aksara 